\title{
Modeling a Three-Stage Biological Trickling Filter Based on the A2O Process for Sewage Treatment
}

\author{
Jiabin Liang ${ }^{1, *}$, Yuan Yuan ${ }^{2, *}$, Zimeng Zhang ${ }^{1}$, Shijie You ${ }^{1}$ and Yixing Yuan ${ }^{1}$ \\ 1 State Key Laboratory of Urban Water Resource and Environment, School of Environment, \\ Harbin Institute of Technology, Harbin 150090, China; hitzzm1997@163.com (Z.Z.); sjyou@hit.edu.cn (S.Y.); \\ yyx1957@163.com (Y.Y.) \\ 2 School of Biological Engineering, Beijing Polytechnic, Beijing 100176, China \\ * Correspondence: LiangJiabin1234@foxmail.com (J.L.); yy12251@126.com (Y.Y.)
}

check for updates

Citation: Liang, J.; Yuan, Y.; Zhang,

Z.; You, S.; Yuan, Y. Modeling a

Three-Stage Biological Trickling Filter Based on the A2O Process for Sewage Treatment. Water 2021, 13, 1152 https://doi.org/10.3390/ w13091152

Academic Editor: Luiza Campos

Received: 13 March 2021

Accepted: 19 April 2021

Published: 22 April 2021

Publisher's Note: MDPI stays neutral with regard to jurisdictional claims in published maps and institutional affiliations.

Copyright: (c) 2021 by the authors. Licensee MDPI, Basel, Switzerland. This article is an open access article distributed under the terms and conditions of the Creative Commons Attribution (CC BY) license (https:// creativecommons.org/licenses/by/ $4.0 /)$.

\begin{abstract}
Biological trickling filters are widely used for sewage treatment. This study models a biological trickling filter based on an anaerobic-anoxic-oxic process (A2O-BTF), established by a combination of aerobic and anaerobic technology. The performance and operational parameters were analyzed using Sumo, a commercially available wastewater treatment process (WWTP) simulation software. The wastewater treatment performance of the anaerobic-anoxic-oxic process biological trickling filter (A2O-BTF), the conventional three-stage biological trickling filter (Three-Stage-BTF), and the single-stage biological trickling filter (Single-BTF) was compared, which indicated the higher performance of $\mathrm{A} 2 \mathrm{O}-\mathrm{BTF}$ in terms of $\mathrm{COD}, \mathrm{TN}, \mathrm{NH}_{3}-\mathrm{N}$, and TP removal. The operational parameters of A2O-BTF were optimized by Sumo simulation software, and the results showed that the removal efficiency of pollutants was increased by raising the temperature to the range of $13.94-21.60{ }^{\circ} \mathrm{C}$. The dissolved oxygen (DO) in the aerobic reactor enhanced removal efficiency under a saturation concentration of 2.2-2.6 $\mathrm{g} \mathrm{O}_{2} / \mathrm{m}^{3}$. In addition, the optimization of the reflux ratio promoted the removal efficiency of the pollutants, indicated by the maximum removal efficiency of COD and TN, achieved at the reflux ratio of 2.25 , and that of $\mathrm{NH}_{3}-\mathrm{N}$ and $\mathrm{TP}$, achieved at a reflux ratio of 0.75 . This study provides a proof-in-concept demonstration that software modeling can be a useful tool for assisting the optimization of the design and operation of sewage treatment processes.
\end{abstract}

Keywords: biological trickling filter; A2O; dissolved oxygen; temperature; reflux ratio

\section{Introduction}

Biological methods are widely used for wastewater treatment processes (WWTPs) [1,2]. As biological reinforcement is a simple and effective technology, it is widely used in wastewater treatment at present [3]. In the cold northern region, the low temperature in winter and temperature difference throughout the year leads to great changes in the activity of microorganisms in the different seasons [4]. Therefore, it is of particular importance to maintain the treatment effect of microorganisms in different climatic conditions. In particular, ordinary heterotrophic organisms (OHOs), ammonia-oxidizing bacteria (AOB), nitrite-oxidizing bacteria (NOB), and phosphorus-accumulating organisms (PAOs) play an important role in the process of denitrification and phosphorus removal [3,5-8].

WWTPs refer to the establishment of an effective wastewater treatment method based on related technologies [9]. Anaerobic-anoxic-oxic (A2O) [10,11], sequence batch reactor (SBR) [12,13], moving bed biofilm reactor (MBBR) [14,15], and integrated fixed-film activated sludge (IFAS) [14] are the commonly used WWTPs. Among them, A2O is the most popular process for nitrogen and phosphorus removal. It operates alternately through anaerobic, anoxic, and aerobic reactions by returning the mixture of liquid and sludge through reflux to achieve the removal of COD, nitrogen, and phosphorus.

Biological trickling filters (BTFs) are a kind of artificial biological treatment technology developed using an intermittent sand filter and a contact filter based on the principle of soil 
self-purification and the practice of sewage irrigation [16]. The BTF is a new type of biofilm technology that integrates biodegradation and solid-liquid separation. The BTF allows long periods of starvation without rinsing out the biomass, which has the advantages of lower energy consumption and lower biomass production compared with an activated sludge system [17,18]. This makes it effective for the treatment of winery wastewater [19], sewage treatment [20], dairy wastewaters [21], and textile wastewater [22].

In the BTF process, several factors such as temperature, dissolved oxygen (DO), and reflux ratio (RR) can have impacts on treatment performance [23-25]. Therefore, the reliability of the system can be increased by a multistage BTF based on the A2O process (A2O-BTF). However, there is a need for the optimization of parameters relevant to design and operation. For example, temperature can exert a major influence on physiological characteristics, microbial growth rate, microbial activity, and microbial community structure [26-28]. Oxygen serves as the electron acceptor, and there is a definite relationship between organic degradation and oxygen demand [29,30]. Watari [31] reported a significant impact of DO concentrations on microbial community and biomass in BTFs. Abou-Elela [32] investigated the effect of media depth, hydraulic retention time (HRT), DO, and surface area of the media on the removal efficiency of pollutants. The reflux ratio (RR) is an important parameter that affects both hydraulic and sludge retention times of the process, providing the backflow of nitrification liquid [33]. Besides that, RR also has a close connection with energy consumption.

Numerical simulations and experimental research are both effective strategies for studying WWTPs. At present, experimental studies on sewage treatment are mostly done on the structural transformation and process upgrades of WWTPs [34]. For example, Cao et al. [35] applied an improved four-stage segmented process to treat low $\mathrm{C} / \mathrm{N}$ urban sewage, and they found that the flow distribution ratio of the four-stage $\mathrm{A} / \mathrm{O}$ was 20:35:35:10. At this time, the average effluent $\mathrm{COD}, \mathrm{NH}_{3}-\mathrm{N}, \mathrm{TN}$, and TP concentrations of the system were $33.05,0.58,9.26$, and $0.46 \mathrm{mg} \cdot \mathrm{L}^{-1}$, respectively. Peng et al. [36] also achieved deep denitrification and phosphorus removal in a three-stage segmented process. However, it should be realized that experimental studies are labor- and time-consuming; most of the current experimental studies are based on the impact of a single factor. There are relatively few systematic studies performed on the impact of multiple factors such as temperature, $\mathrm{DO}$, and reflux ratio in integrated reactor systems.

Numerical simulation offers a theoretical manner to optimize the operating parameters of a complex WWTP system. The widely used models include the activated sludge models (ASMs) [37,38] and the anaerobic digestion models (ADMs) $[39,40]$ developed by International Water Association (IWA). The ASMs can simulate organic degradation, nitrification, and denitrification, as well as biological phosphorus removal. Baek et al. [41] studied the performance of the aerobic membrane bioreactor (MBR) process in terms of COD removal and ammonia-nitrogen nitrification. Tao et al. [14] simulated the partial nitrification anammox (PN/A) process of moving bed biofilm reactor (MBBR) and integrated fixed-film activated sludge (IFAS). Cramer et al. [16] investigated the decay of heterotrophic biomass in biofilms of trickling filters. To simulate the WWTP more effectively, the ASMs and ADMs are integrated into the software package that includes Biowin, Gps-x, West, and Sumo, among others. Among them, Sumo is a newly explored platform that has the advantages of high simulation efficiency and open source code, making it available for wide range of applications in the simulation of sewage treatment [14,42,43]. However, there are few studies on the multiple-stage biological filter treatment system based on the A2O process (A2O-BTF).

Owing to the hydraulic load of BTF, the cultivation of relevant bacteria in the nitrification process is limited in steady-state simulation [44-46]. In this context, dynamic simulation can be used to analyze the change in the effluent when the influent hydraulic load and the organic load are varied. To address the issues of optimal scheduling of BTFs under dynamic conditions and low treatment efficiency in cold regions, a three-stage BTF was employed to verify the feasibility of the models developed by Sumo software. The 
full-field simulation models of A2O-BTF were established by changing the form of aeration and adding reflux units. The sewage treatment of A2O-BTF, Three-stage-BTF, and Single-BTF was compared. The simulated parameters were set by temperature in the range of $13.95-21.60{ }^{\circ} \mathrm{C}$, DO in an aerobic aeration tank of $0.2-4 \mathrm{~g} \mathrm{O}_{2} / \mathrm{m}^{3}$, and a mixed liquid reflux ratio of $0.5-2.5$, respectively. The impacts of the operating parameters on COD, $\mathrm{TN}$, $\mathrm{NH}_{3}-\mathrm{N}$, and TP removal were analyzed, and the content of major microorganisms such as $\mathrm{OHO}, \mathrm{AOB}, \mathrm{NOB}$, and $\mathrm{PAO}$ in the sludge was compared under different conditions. The modeled results were validated by experimental data.

\section{Materials and Methods}

\subsection{Experimental Setup}

This experiment device is shown in Figure 1. The length and width of the reactor were $16 \times 17 \mathrm{~cm}$. Each trickling filter reactor was divided into three layers; the height of the upper layer was $15 \mathrm{~cm}$, and the height of the middle and bottom layers were 15 and $30 \mathrm{~cm}$, respectively. The filler in the upper, middle, and bottom layers of the No. 1 reactor was clinoptilolite, biological ceramsite, and coke. Similarly, the filler's combination in the No. 2 and No. 3 reactors was clinoptilolite, coke, and sponge iron. We set up a mixed liquid return device and a sludge return device after the No. 3 reactor and returned the liquid through a peristaltic pump. Additionally, we set up an aeration device in the No. 3 reactor to construct an A2O-BTF process. At the same time, the single-stage trickling filter wastewater treatment process (Single-BTF) and the three-stage trickling filter process (Three-Stage-BTF) were used as two comparative processes. The Three-Stage-BTF dismantles the reflux device and simultaneously aerates the No. 1 and No. 3 reactors. The process is similar to the process in the literature [47]. The Single-BTF dismantles the No. 1 and No. 2 reactors and operates the No. 3 reactor separately. The experimental water was simulated domestic sewage, constructed from glucose, ammonium chloride, potassium dihydrogen phosphate, and magnesium sulfate. The influent parameters of the simulated sewage are shown in Table 1 . The measurement of COD, TN, $\mathrm{NH}_{3}-\mathrm{N}$, and TP were all determined by the standard method. Hach reagent tube was employed for COD and TN measurement. $\mathrm{NH}_{3}-\mathrm{N}$ was measured by Nessler's reagent colorimetry, and TP was measured by molybdenum antimony spectrophotometry. All experiments were conducted with at least two parallel samples.

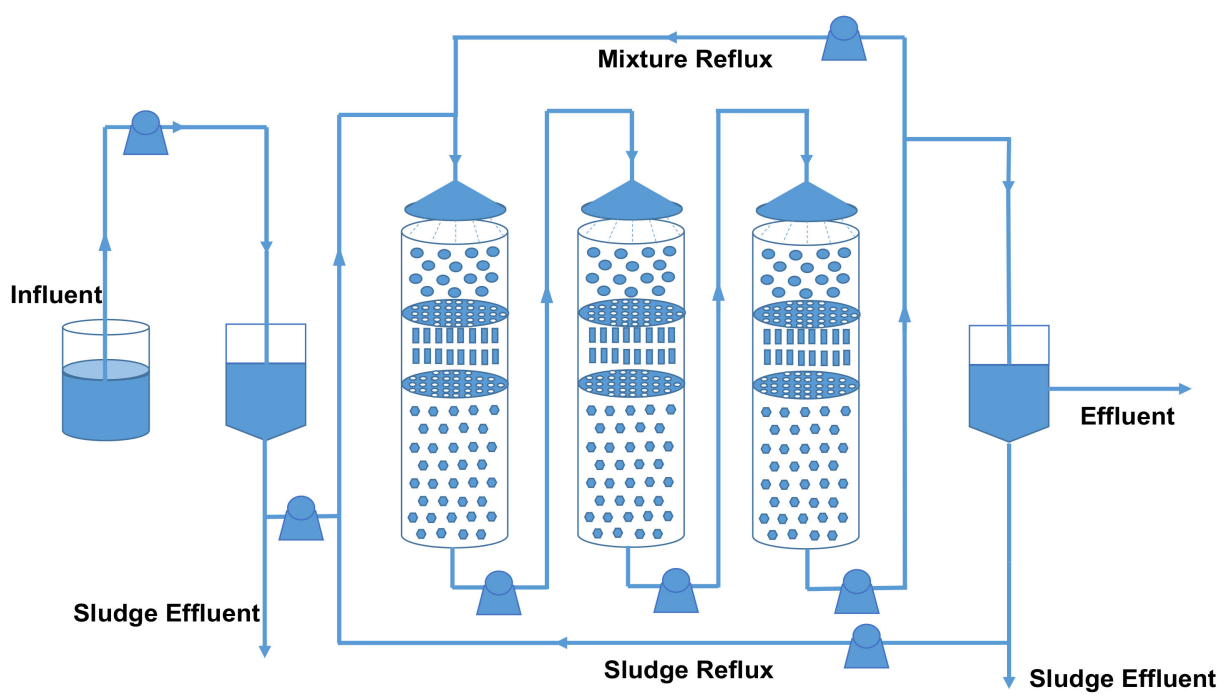

Figure 1. Experiment device. 
Table 1. Influent parameters.

\begin{tabular}{ccc}
\hline Name & Value & SI Unit \\
\hline Total COD & $310-807$ & $\mathrm{~g} \mathrm{COD} / \mathrm{m}^{3}$ \\
TKN & $31.00-46.50$ & $\mathrm{~g} \mathrm{~N} / \mathrm{m}^{3}$ \\
Total Phosphorus & $3.46-4.56$ & $\mathrm{~g} \mathrm{P} / \mathrm{m}^{3}$ \\
Fraction of $\mathrm{NH}_{3}$ in TKN & $88.00-93.50$ & $\%$ \\
PH & 6 & - \\
Influent cBOD & 200 & $\mathrm{mg} \mathrm{BOD} / \mathrm{L}$ \\
Flow Rate & 0.027 & $\mathrm{~m}^{3} / \mathrm{d}$ \\
PO4 Fraction of TP & 58.14 & $\%$ \\
\hline
\end{tabular}

\subsection{Models}

In this paper, the treatment effect of the sewage treatment plant was simulated through the wastewater treatment process (WWTP) simulation software Sumo. The whole simulation route is shown in Figure 2. The modeling process includes the establishment of the process flow sheet, the selection of the model, the setting of water inlet parameters, and the setting of wastewater treatment plant operating parameters.

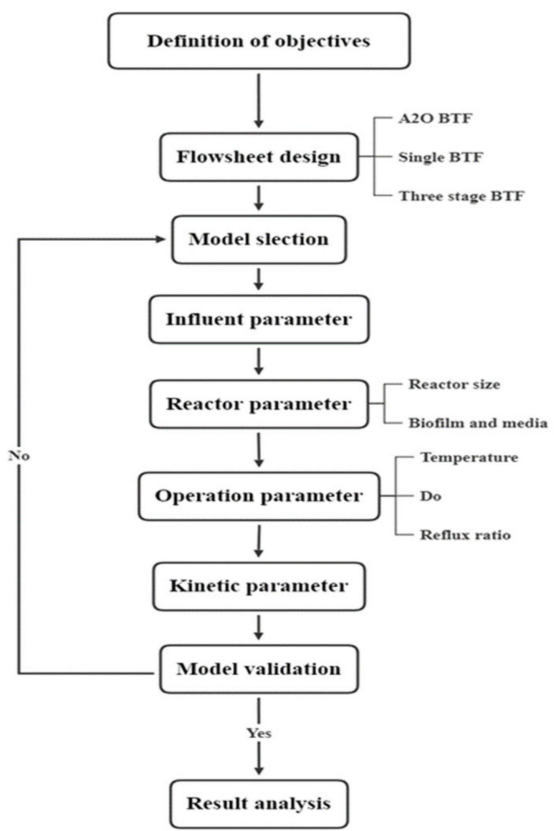

Figure 2. Simulation route map.

The flow sheet of the trickling filter based on the A2O process (A2O-BTF) is shown in Figure 3. The first reactor uses an anaerobic trickling filter, the second reactor uses an anoxic trickling filter, and the third trickling filter adopts the method of calculating dissolved oxygen; oxygen is introduced into the trickling filter. A primary sedimentation tank was arranged in front of the anaerobic reactor, a secondary sedimentation tank was arranged behind the reactor. Further more, a mixed-liquid reflux device and a sludge reflux device were arranged in this system. 


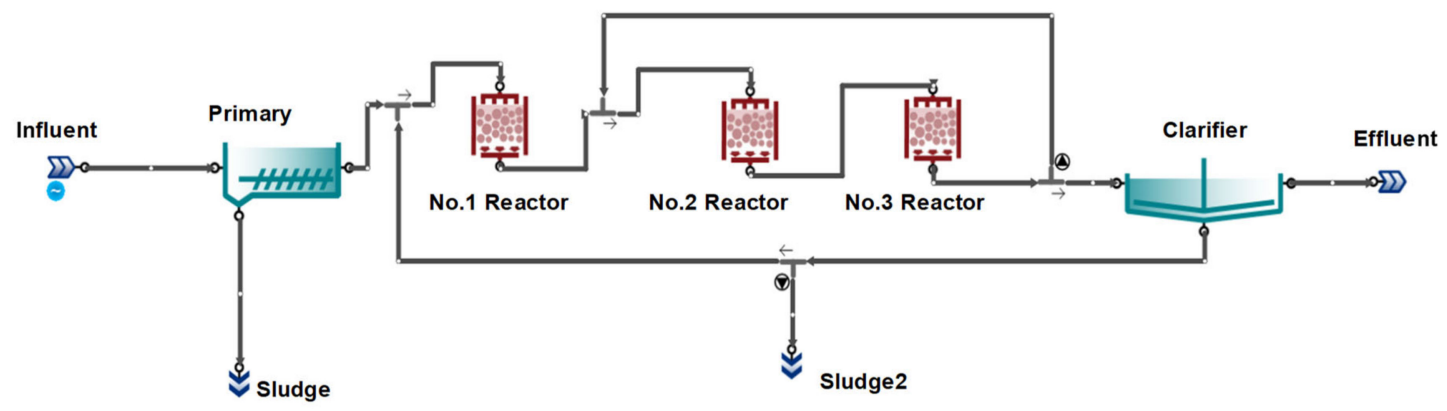

Figure 3. Flow sheet of A2O-BTF.

The flowsheets of Three-Stage-BTF and Single-BTF are shown in Figure 4. The feasibility of the simulation was verified by experiment. The surface area of the biological trickling filter reactor was $0.027 \mathrm{~m}^{2}$, and the height was $0.6 \mathrm{~m}$. In this document, the Three-Stage-BTF adopts the aerobic-anoxic-aerobic method, and there is no reflux device. This would lead to a lack of an anaerobic sewage treatment environment, resulting in incomplete ammoniation of organic matter. At the same time, the lack of nitrification liquid and sludge return affects its denitrification and the biological phosphorus removal process. This article will verify the model by a comparison of experiment values, so during the comparison process, we will not only present the simulated values but also some experimental values. On this basis, the aeration method was changed, and a reflux device was added to construct a three-stage trickling filter process similar to A2O-BTF. Single-BTF was applied as a comparative group to compare the wastewater treatment effects of the other reactors. A2O-BTF, Three-Stage-BTF, and Single-BTF were tested under the same parameters. The operating parameters of the A2O-BTF process were optimized, and the influence of temperature, dissolved oxygen (DO), and mixed reflux ratio on the A2O-BTF process was analyzed.

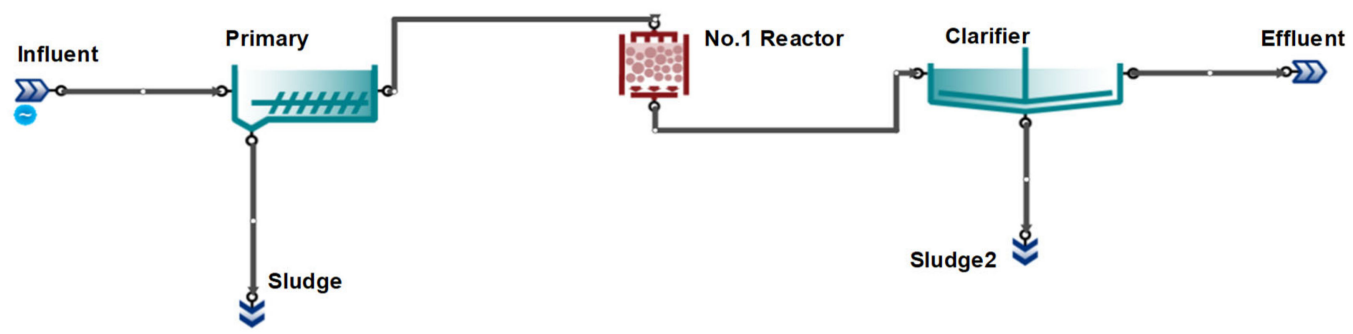

A

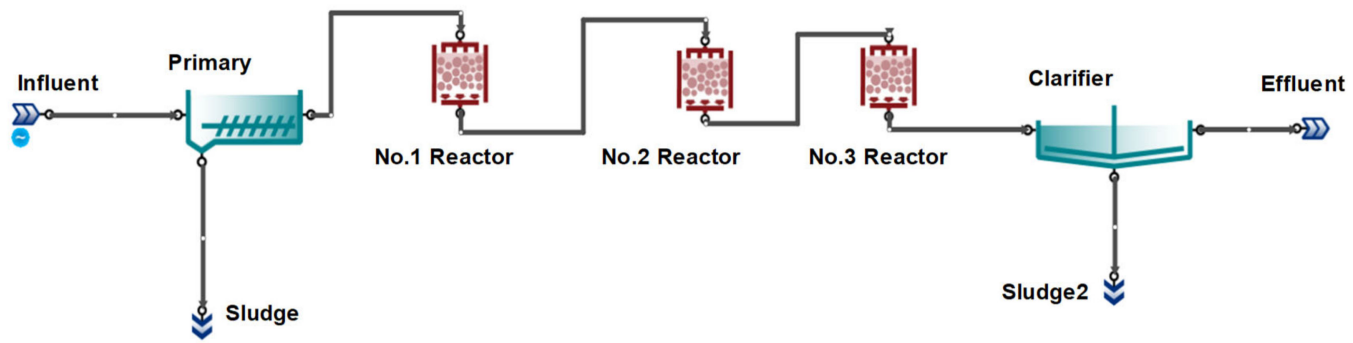

Figure 4. Flow sheets of the comparative group: (A) Single-BTF; (B) Three-Stage-BTF.

The basis of the activated sludge model is from the Monod equation that expresses cell growth kinetics, combined with the reactor theory and the microbiology theory in the 
chemical industry, to quantitatively describe the mathematical relationship between matrix degradation and microbial growth and other parameters. The Monod equation is

$$
\mu=\mu_{\max } \frac{S}{K_{s}+S}
$$

where $\mu$ indicates the specific growth rate of microorganisms, $\mu_{\max }$ indicates the maximum growth rate of microorganisms, $S$ indicates organic substrate concentration, and $K_{s}$ indicates saturation-constant microorganisms.

In addition, there is a certain relationship between organic matter degradation and oxygen demand.

$$
\mathrm{O}_{2}=a^{\prime} Q S_{\mathrm{r}}+b^{\prime} V X_{\mathrm{V}}
$$

$\mathrm{O}_{2}$ indicates the oxygen demand of the mixed liquid in the aeration tank, $a^{\prime}$ indicates the oxygen demand of activated sludge microorganisms for the catabolism of organic matter, $Q$ indicates sewage flow, $S_{\mathrm{r}}$ indicates the amount of organic pollutants degraded by activated sludge microbial catabolism, $b^{\prime}$ indicates the activated sludge microorganisms that endogenously metabolize their oxygen demand for bacterial self-oxidation, $V$ is the volume of the reactor, and $X_{\mathrm{v}}$ is the mixed liquid volatile suspended solids (MLVSSs) per unit volume of the aeration tank.

\subsection{Working Conditions}

The experimental values were used to verify the feasibility of the model, and the wastewater treatment performance of the three processes of A2O-BTF, Single-BTF, and Three-Stage-BTF were compared. The optimization indexes of the operating parameters in this paper were the temperature of the reactor, the dissolved oxygen (DO) of the aerobic reactor, and the change of the reflux ratio of the mixed liquid. Since the biological trickling filter (BTF) is essentially a membrane process and is less affected by the sludge reflux ratio, this article did not analyze the influence of the sludge reflux ratio. The sludge reflux ratio adopted the default value under all working conditions. The default operating parameters of the reactor are shown in Table 2. These parameters were used in the model verification and comparison of A2O-BTF, Single-BTF, and Three-Stage-BTF.

Table 2. Default operating parameters of the reactor.

\begin{tabular}{ccc}
\hline Name & Value & SI Unit \\
\hline Temperature & 20.00 & ${ }^{\circ} \mathrm{C}$ \\
Desired DO Setpoint of & 2 & $\mathrm{~g} \mathrm{O}_{2} / \mathrm{m}^{3}$ \\
No. 3 Reactor & 1.25 & - \\
Mixture Reflux Ratio & 1 & - \\
Sludge Reflux Ratio & 1 & - \\
\hline
\end{tabular}

In addition to the difference in process configuration, the aeration method was also different between the three processes. Single-BTF could be regarded as an aerobic process, and the DO of the reactor was $2 \mathrm{~g} \mathrm{O}_{2} / \mathrm{m}^{3}$. Three-Stage-BTF adopted the aerobic-anoxicaerobic method; the $\mathrm{DO}$ of the first and third reactors in the simulation process was $2 \mathrm{~g} \mathrm{O}_{2} / \mathrm{m}^{3}$, and the second reactor used the calculated dissolved oxygen. A2O-BTF used a combination of anaerobic-anoxic-aerobic; the DO of the first reactor was $0 \mathrm{~g} \mathrm{O}_{2} / \mathrm{m}^{3}$, the second reactor used calculated dissolved oxygen, and the third reactor was an aerobic reactor. The default DO was $2 \mathrm{~g} \mathrm{O}_{2} / \mathrm{m}^{3}$ of the third reactor, and it would be optimized later to analyze the influence of different levels of $\mathrm{DO}$ on the effluent contaminant concentration and reactor microorganisms.

The operating conditions of the A2O-BTF process under different conditions were analyzed, and the optimized parameter ranges of each process are shown in Table 3. When optimizing one of the parameters, the other parameters were still the default settings. The dynamic simulation method was adopted to dynamically simulate the changes of contaminant concentrations of wastewater. This article focuses on analyzing the removal of 
$\mathrm{COD}, \mathrm{NH}_{3}-\mathrm{N}, \mathrm{TN}$, and TP. Since microorganisms have a greater impact on treatment effect, the biomass of $\mathrm{OHOs}, \mathrm{AOB}, \mathrm{NOB}$, and $\mathrm{PAOs}$ in each reactor should be analyzed during the optimization process. The reaction process was optimized by analyzing the pollutant removal rate under the action of various operating parameters.

Table 3. Optimized parameters of the A2O-BTF process.

\begin{tabular}{ccc}
\hline Name & Value & SI Unit \\
\hline Temperature & $13.95-21.60$ & ${ }^{\circ} \mathrm{C}$ \\
Desired DO Setpoint of & $0.2-4$ & $\mathrm{~g} \mathrm{O}_{2} / \mathrm{m}^{3}$ \\
No. 3 Reactor & $0.50-2.50$ & - \\
Mixture Reflux Ratio & & - \\
\hline
\end{tabular}

\subsection{Operating Parameters}

This paper adopts the 2-step nitrification/denitrification model in Sumo software, which simplifies the process of nitrogen and phosphorus removal, focusing on the intermediate product in the reaction process- $-\mathrm{NO}_{2}{ }^{-}-\mathrm{N}$. The optimized operating parameters that are mainly analyzed in this paper include temperature, dissolved oxygen (DO), and the reflux ratio of the mixed liquor. Changing the dissolved oxygen (DO) and reflux ratio would not affect the reaction kinetic parameters, but with the changing of temperature, the reaction kinetic parameters would be varied. The reaction kinetic parameters of the model at $20{ }^{\circ} \mathrm{C}$ are shown in Table 4 . The reaction kinetic parameters were used for model verification, comparison of A2O-BTF, Single-BTF, Three-Stage-BTF, and the optimization of dissolved oxygen (DO) and mixed reflux ratio in the A2O-BTF process.

Table 4. Main kinetic parameters of the reaction.

\begin{tabular}{|c|c|c|}
\hline Name & Value & Unit \\
\hline COD of biodegradable substrate in volatile solids & 1.60 & g COD.g VSS ${ }^{-1}$ \\
\hline COD of particulate unbiodegradable organics in volatile solids & 1.30 & g COD.g VSS ${ }^{-1}$ \\
\hline COD of biomass in volatile solids & 1.42 & g COD.g VSS ${ }^{-1}$ \\
\hline COD of endogenous products in volatile solids & 1.42 & g COD.g VSS ${ }^{-1}$ \\
\hline Maximum specific growth rate of AOBs & 0.85 & $1 / \mathrm{d}$ \\
\hline Half-saturation of $\mathrm{O}_{2}$ for AOBs (AS) & 0.25 & $\mathrm{~g} \mathrm{O}_{2} / \mathrm{m}^{3}$ \\
\hline Half-saturation of $\mathrm{O}_{2}$ for NOBs (AS) & 0.25 & $\mathrm{~g} \mathrm{O}_{2} / \mathrm{m}^{3}$ \\
\hline Half-saturation of $\mathrm{NH}_{3}$ for AOBs (AS) & 0.50 & $\mathrm{~g} \mathrm{~N} / \mathrm{m}^{3}$ \\
\hline Maximum specific growth rate of NOBs & 0.65 & $1 / \mathrm{d}$ \\
\hline Maximum specific growth rate of $\mathrm{OHOs}$ & 4.00 & $1 / \mathrm{d}$ \\
\hline Half-saturation of $\mathrm{NO}_{2}$ for NOBs (AS) & 0.10 & $\mathrm{~g} \mathrm{~N} / \mathrm{m}^{3}$ \\
\hline Half-saturation of readily biodegradable substrate for OHOs (AS) & 5.00 & $\mathrm{~g} \mathrm{COD} / \mathrm{m}^{3}$ \\
\hline Half-saturation of $\mathrm{O}_{2}$ for $\mathrm{OHOs}(\mathrm{AS})$ & 0.15 & $\mathrm{~g} \mathrm{O}_{2} / \mathrm{m}^{3}$ \\
\hline Maximum specific growth rate of PAOs & 1.00 & $1 / \mathrm{d}$ \\
\hline Half-saturation of $\mathrm{PO}_{4}$ for PAOs (AS) & 0.50 & $\mathrm{gP} / \mathrm{m}^{3}$ \\
\hline Rate of hydrolysis & 2.00 & $1 / \mathrm{d}$ \\
\hline
\end{tabular}

The treatment effect of A2O-BTF under different temperature conditions would have a certain impact, which is mainly reflected in the growth rate and decay rate of bacteria, so its kinetic parameters need to be adjusted. The study [48] has corrected the sensitive kinetic parameters at different temperatures based on the data provided by a wastewater treatment plant. The correction parameters were used in this paper, as shown in Table 5. 
Table 5. Adjustment of the main parameters at different temperatures [48].

\begin{tabular}{|c|c|c|c|c|}
\hline Temp & Parameter & Default & Value & Unit \\
\hline \multirow{2}{*}{$13.94^{\circ} \mathrm{C}$} & Maximum specific growth rate of AOBs & 0.85 & 0.71 & $1 / \mathrm{d}$ \\
\hline & Maximum specific growth rate of $\mathrm{OHOs}$ & 4.00 & 4.40 & $1 / \mathrm{d}$ \\
\hline \multirow{5}{*}{$21.60^{\circ} \mathrm{C}$} & Maximum specific growth rate of AOBs & 0.85 & 0.62 & $1 / \mathrm{d}$ \\
\hline & Decay rate of AOBS & 0.17 & 0.20 & $1 / \mathrm{d}$ \\
\hline & Maximum specific growth rate of $\mathrm{OHOs}$ & 3.20 & 5.00 & $1 / \mathrm{d}$ \\
\hline & Half-saturation of $\mathrm{O} 2$ for $\mathrm{OHOs}$ & 5.00 & 2.00 & $\mathrm{~g} \mathrm{O}_{2} / \mathrm{m}^{3}$ \\
\hline & Reduction factor for anoxic growth of OHOs & 0.60 & 0.65 & \\
\hline \multirow{4}{*}{$16.60^{\circ} \mathrm{C}$} & Maximum specific growth rate of AOBs & 0.90 & 0.66 & $1 / \mathrm{d}$ \\
\hline & Decay rate of AOBS & 0.17 & 0.20 & $1 / \mathrm{d}$ \\
\hline & Maximum specific growth rate of $\mathrm{OHOs}$ & 3.20 & 4.60 & $1 / \mathrm{d}$ \\
\hline & Reduction factor for anoxic growth of OHOs & 0.60 & 0.65 & \\
\hline
\end{tabular}

The application of different fillers has a great impact on the treatment effect of the trickling filter. The biological trickling filter (BTF) reactor in Sumo is based on the biofilm method and provides several common filler parameters. By adjusting the filler parameters, the wastewater treatment effect can be affected. This study used the same volume of the trickling filter reactor as in the literature [47], and the trickling filter reactor was divided into three layers. By adjusting the filler parameters, the simulated values were as close to the experimental values as possible.

\section{Results and Discussion}

\subsection{Modeling Verification and Process Comparison}

The comparison of the treatment effects of different processes is shown in Figure 5. The wastewater treatment performances of Single-BTF, Three-Stage-BTF, and A2O-BTF were compared, and the simulation results were compared with the experiment results. Under normal circumstances, an error within $20 \%$ between the experimental values and the simulated values is considered a reasonable result. It can be seen from Figure 5 that by adjusting the main reaction kinetic parameters and the combination of biological trickling filter (BTF) fillers, the simulation results were basically consistent with the experimental results, and wastewater treatment performance could be basically reflected by the simulation results. It can be seen from Figure 5 that the simulated values of COD, TN, and TP are basically the same as the experimental values, and the experimental values were almost within $\pm 20 \%$ of the simulated value. For $\mathrm{NH}_{3}-\mathrm{N}$, because of the magnitude of the effluent pollutant, which is generally less than $0.3 \mathrm{~g} \mathrm{~N} / \mathrm{m}^{3}$, there would be a bit of error in the measurement process of the experiment. In the simulation process, due to dynamic simulation, the initial value and related parameters of process simulation can cause differences in the simulation values and actual values. However, there is still a bit of deviation between the simulation and the experiment. From the description of the equation, we know that the growth rate of microorganisms, the half-saturation constant, and the rate of metabolism of organic matter are the main factors that affect the accuracy of the simulation. The commercial software Sumo completes the related models and integrates more parameters to better ensure the accuracy of the simulation. Taking into account different experimental environments, these parameters need to be calibrated manually. The variation of temperature would affect the growth rate of microorganisms; meanwhile, the application of different fillers would affect the half-saturation constant of the microorganisms in the reactor. The adjusted parameters are shown in Tables 4 and 5. However, the above calibrated parameters cannot be completely consistent with the actual conditions of microbial growth and metabolism, which leads to simulation deviations from the experiment. 

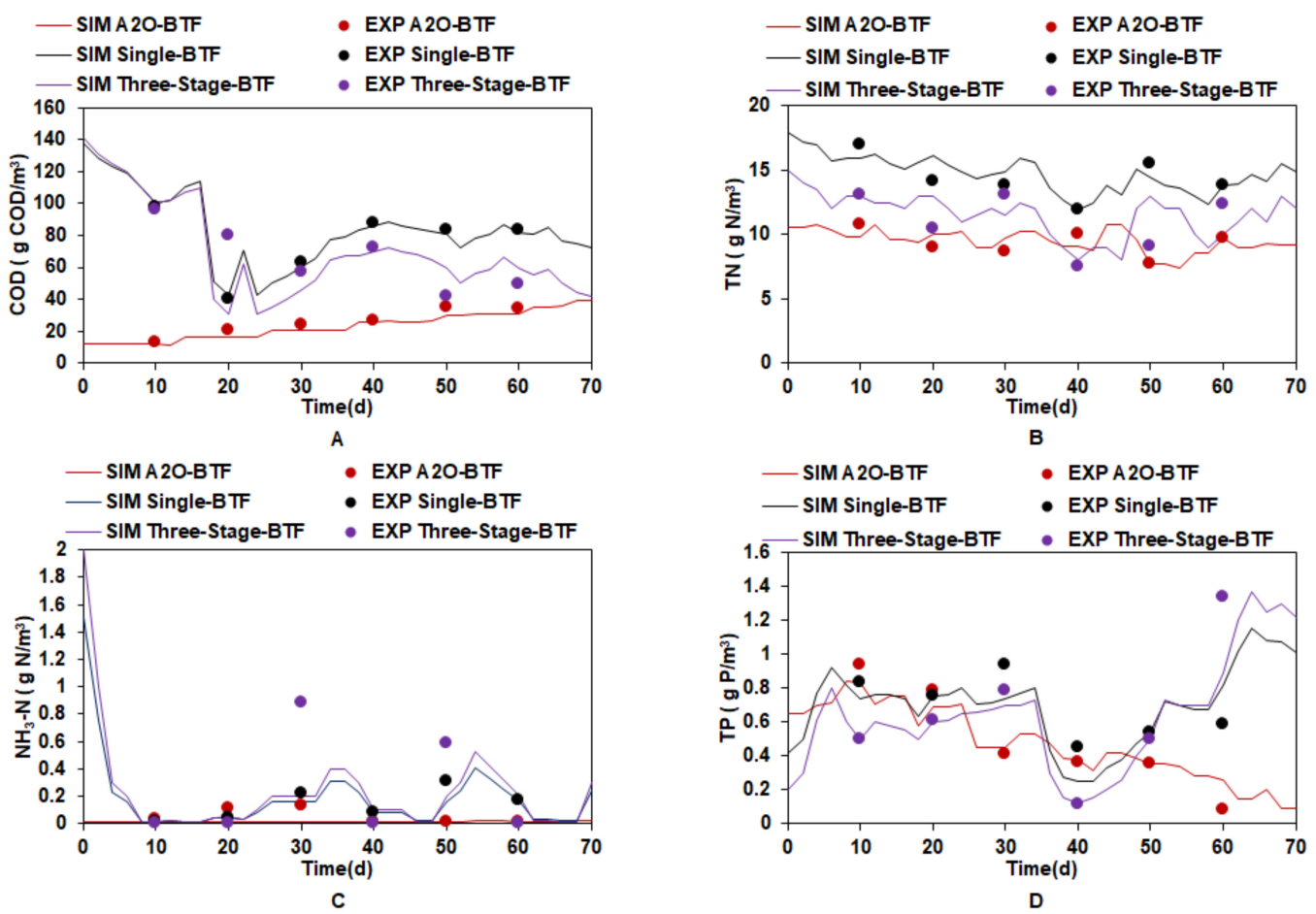

Figure 5. Comparison of different wastewater treatment processes: (A) COD; (B) $\mathrm{TN}$; (C) $\mathrm{NH}_{3}-\mathrm{N}$; (D) TP.

The aeration method of Single-BTF and Three-Stage-BTF is similar, and the desired DO setpoint of the reactor is $2 \mathrm{~g} \mathrm{O}_{2} / \mathrm{m}^{3}$. The treatment performance of A2O-BTF was better than that of Single-BTF and Three-Stage-BTF. Among them, in the early stage of wastewater treatment, A2O-BTF had better treatment performance for $\mathrm{COD}$ and $\mathrm{NH}_{3}-\mathrm{N}$ than Three-Stage-BTF and Single-BTF. Compared with Single-BTF, A2O-BTF possessed a longer pollutant treatment path due to the addition of multistage reaction devices so that pollutants could be treated more adequately. Compared with Three-Stage-BTF, A2O-BTF returns the main pollutants to the anoxic reactor at the beginning of the reaction by the action of reflux, thereby reducing the emission of pollutants in the initial stage and, at the same time, increasing the anaerobic environment so that anaerobic bacteria can more adequately treat the related pollutants.

\subsection{The Influence of Temperature}

The removal effect of each effluent indicator under different temperature conditions is shown in Figure 6. As the temperature rises, the main sewage effluent indicators decline. Among them, COD, TN, and TP all showed relatively regular changes; that was, as the temperature increased, the sewage treatment effect was enhanced, and the pollutant effluent data were reduced. As for phosphorus, because phosphorus-accumulating organisms (PAOs) are also a kind of bacteria with better cold tolerance, the effect of temperature on phosphorus removal was not as significant as that on nitrification. However, due to the low temperature, it was affected by sludge expansion and microbial deposition, so that the phosphorus effluent concentration also decreased as the temperature increased [49-51]. In the actual operation of urban sewage treatment plants in cold regions in winter, it was found that the activity of PAOs still exists in low-temperature environments; some inhibitory microorganisms grow rapidly, and nitrates have a strong inhibitory effect on anaerobic phosphorus release. Therefore, phosphorus removal capacity would have a certain tendency to decline under low-temperature conditions $[4,52,53]$. 


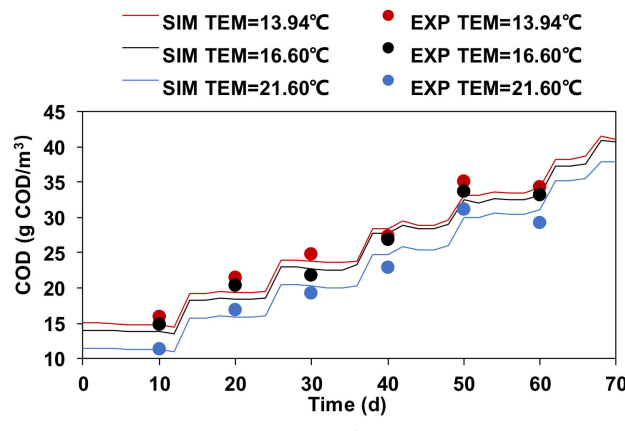

A

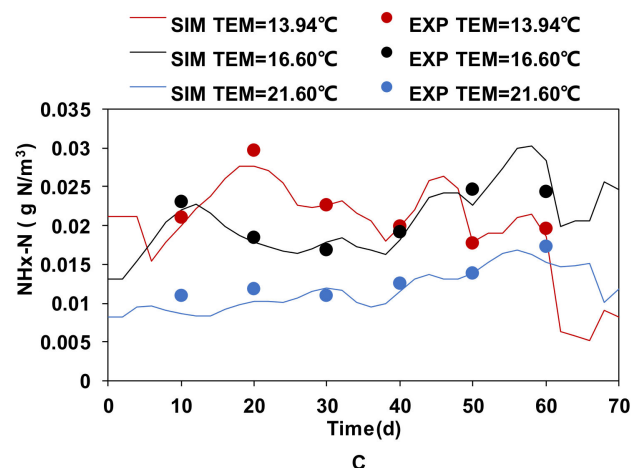

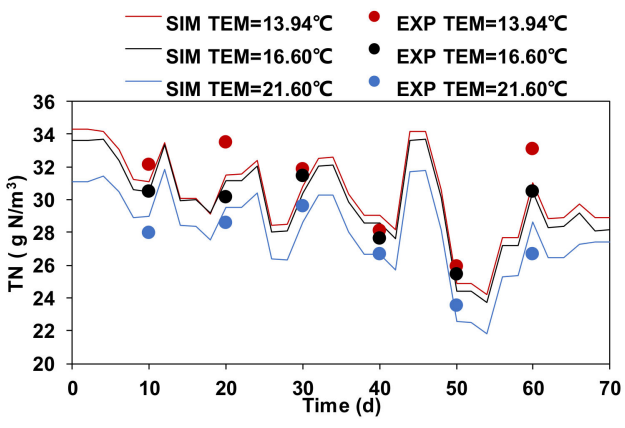

$B$

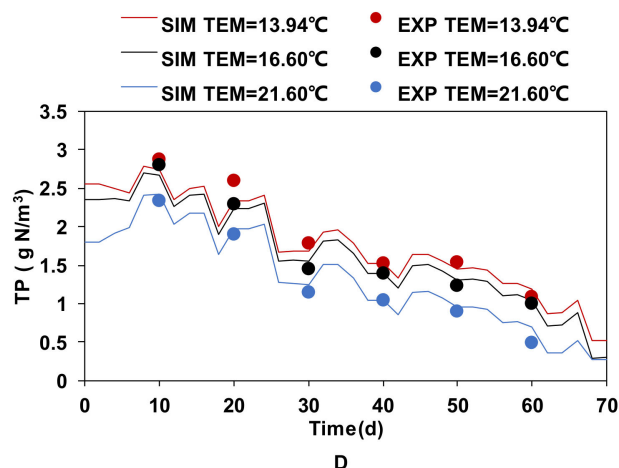

Figure 6. The influence of temperature on the effect of effluent: (A) COD; (B) TN; (C) $\mathrm{NH}_{3}-\mathrm{N}$; (D) TP.

On the one hand, low temperature reduces the activity and metabolism of microorganisms in the anaerobic biological treatment process, which reduces methane production and COD removal efficiency. On the other hand, it causes the accumulation of volatile acid in the system. The drop in system $\mathrm{pH}$ can cause the collapse of the entire anaerobic system by the buffering capacity of the system exceeded. The low temperature of sewage in winter is one of the reasons why activated sludge expansion or sludge expansion is more serious in urban sewage treatment plants. At the same time, low temperatures will also lead to the growth of filamentous bacteria [54,55].

The changing law of pollutant concentrations in effluent is different in different time periods. COD changes with time are more consistent. As the temperature increases, the COD effluent values decrease. Among them, the COD value of each time period of $21.60{ }^{\circ} \mathrm{C}$ decreased by about $30 \%$ compared with $13.94{ }^{\circ} \mathrm{C}$. Similarly, the trend of TN and TP, as affected by temperature, was similar to that of COD, showing a more uniform increasing or decreasing trend with temperature changes. This is due to the decrease in temperature, resulting in a decrease in biological activity in the sewage treatment system. Previous studies have also pointed out this problem. For example, Kumwimba [28] analyzed the purification of agricultural vegetation wastewater in plant drains under low-temperature conditions and pointed out $\mathrm{TN}, \mathrm{NH}_{3}-\mathrm{N}, \mathrm{NO}_{3}-\mathrm{N}, \mathrm{TP}$, and $\mathrm{PO} 4$ under winter conditions- the average reduction efficiency of $\mathrm{P}$ was $44,46,43,52$, and $46 \%$, respectively. Varma [56] pointed out that the construction of a greenhouse system could increase the removal rate of $\mathrm{TN}$ and COD by $20 \%$ in the process of treating coal-water slurry wastewater in a constructed wetland system. The change trend of $\mathrm{NH}_{3}-\mathrm{N}$ is more complicated. In this article, with the increase of temperature, the effluent index of $\mathrm{NH}_{3}-\mathrm{N}$ decreased before $50 \mathrm{~d}$. However, after $50 \mathrm{~d}$, the effluent data of $\mathrm{NH}_{3}-\mathrm{N}$ at $13.94{ }^{\circ} \mathrm{C}$ decreased significantly, while at 16.60 and $21.60^{\circ} \mathrm{C}$, there was no significant change in the water effluent index. There are two reasons for this phenomenon. One is the change in the ammonia nitrogen concentration of the influent water, which has an impact on the effluent effect, and the other is that the accumulation of $\mathrm{TN}$ in the early stage will provide enough ammonia nitrogen in the later stage. 


\subsection{The Influence of Dissolved Oxygen}

3.3.1. The Influence of Dissolved Oxygen on the Effluent

During the operation of the A2O-BTF process, different microorganisms will have a corresponding impact on the effect of sewage treatment. Since the BTF process is essentially a membrane treatment process, its impact on the pollutant treatment effect is similar to other studies on MBBR. Aeration is the main factor affecting pollutant treatment efficiency [57]. It has a greater impact on the treatment of the aerobic section, with emphasis on the removal of COD, phosphorus absorption, and nitrification processes.

In this research, a three-stage $\mathrm{A} 2 \mathrm{O}$ reaction device was established. The first stage reaction device was anaerobic, the desired DO setpoint was zero, and the second stage used the calculation of dissolved oxygen. The third stage adopted aerobic aeration, and the desired DO setpoint was $0.2-4 \mathrm{~g} \mathrm{O}_{2} / \mathrm{m}^{3}$.

The treatment effect of dissolved oxygen on pollutants is shown in Figure 7. As the dissolved oxygen will be saturated in the reactor when it reaches a certain value, the effluent concentration of pollutants will gradually decrease with the increase of dissolved oxygen, at first, and it would be stabilized after reaching the saturation concentration of dissolved oxygen. In this study, the saturation concentration was about 2.2-2.6 $\mathrm{g} \mathrm{O}_{2} / \mathrm{m}^{3}$. For the removal efficiency of COD when dissolved oxygen reaches the saturation concentration, the effluent value increased by about $10 \mathrm{~g} C O D / \mathrm{m}^{3}$, TN increased by about $8-12 \mathrm{~g} \mathrm{~N} / \mathrm{m}^{3}$, and TP increased by $1.1 \mathrm{~g} \mathrm{P} / \mathrm{m}^{3}$ compared with the desired DO setpoint of 0.2 . For $\mathrm{NH}_{3}-\mathrm{N}$, as the aerobic device performs more nitrification reaction, $\mathrm{NH}_{3}-\mathrm{N}$ was effectively converted into nitrate nitrogen and nitrite nitrogen, so the ammonia nitrogen content was lower. With the increase of dissolved oxygen, nitrification was strengthened, which would further reduce the proportion of ammonia nitrogen. When saturated with dissolved oxygen, the treatment efficiency of ammonia nitrogen was increased by $0.007 \mathrm{~g} \mathrm{~N} / \mathrm{m}^{3}$ compared with the effluent of $\mathrm{NH}_{3}-\mathrm{N}$ when no oxygen was supplied.
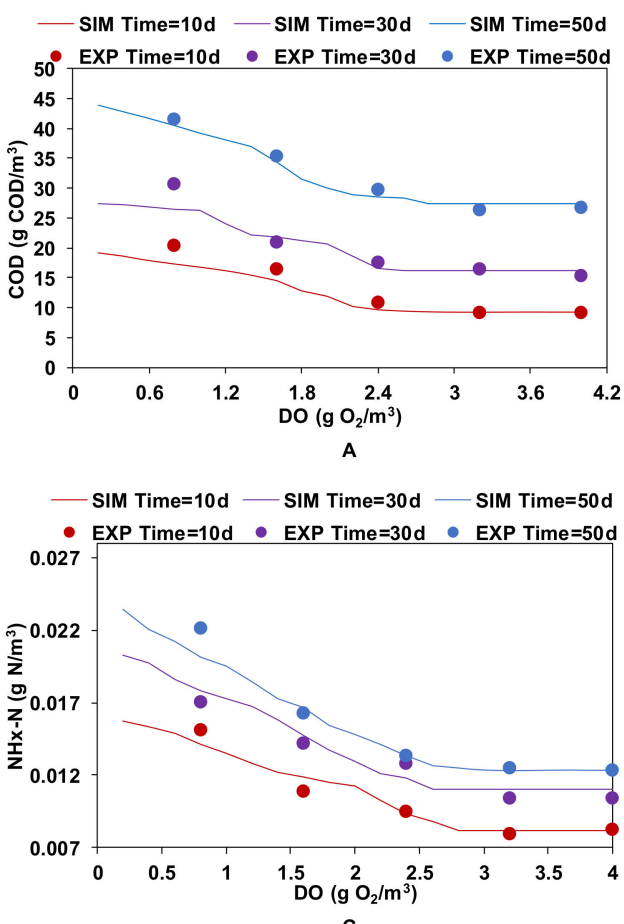

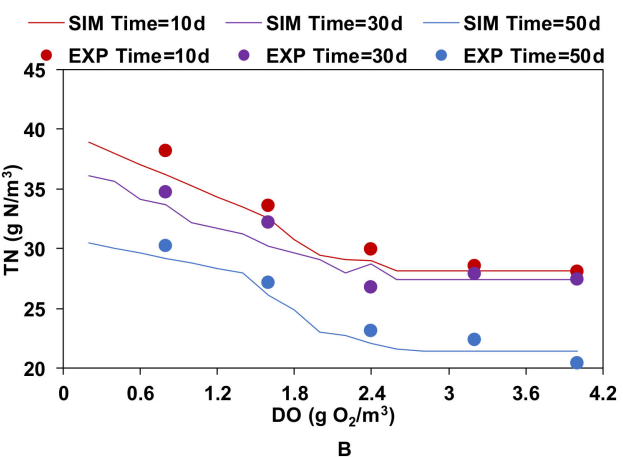

- SIM Time $=10 \mathrm{~d}-$ SIM Time $=30 \mathrm{~d}-$ SIM Time $=50 \mathrm{~d}$

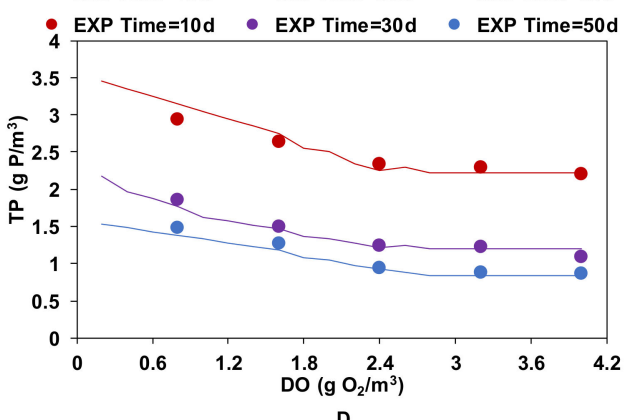

Figure 7. The influence of dissolved oxygen on the water effluent effect: (A) COD; (B) $\mathrm{TN} ;(\mathbf{C}) \mathrm{NH}_{3}-\mathrm{N}$; (D) TP. 


\subsubsection{The Effect of Dissolved Oxygen on Biomass}

This article mainly analyzed the biological distribution of each pollutant under the action of different levels of dissolved oxygen at 30 days, as shown in Figure 8. Among them, $\mathrm{AOB}$ and NOB play a major role in the process of nitrogen removal, $\mathrm{PAO}$ plays a major role in the process of phosphorus removal, and $\mathrm{OHO}$ is responsible for the removal of COD [58]. When the OHO concentration is relatively stable, the COD removal effect is relatively stable. This study adopted partial nitrification anammox (PN/A) technology because partial nitrification anammox (PN/A) technology only oxidizes $\mathrm{NH}_{4}{ }^{+}$to $\mathrm{NO}_{2}{ }^{-}$ instead of traditional $\mathrm{NO}_{3}{ }^{-}$[57]; it includes the following advantages [59-61]: (1) reduction of nitrification oxygen demand by $25 \%$; (2) $40 \%$ in savings of the denitrification carbon source; (3) a higher denitrification rate and a reduction of the volume of the denitrification tank by $50 \%$; (4) nitrification and denitrification processes can reduce sludge production by $24 \sim 33 \%$ and $50 \%$, respectively. In this case, the AOB concentration should be maintained at an appropriate level [14]. At the same time, $\mathrm{NOB}$ would further oxidize $\mathrm{NO}_{2}{ }^{-}-\mathrm{N}$ to $\mathrm{NO}_{3}{ }^{-}-\mathrm{N}$, so too much $\mathrm{NOB}$ would increase the energy consumption of the reaction.
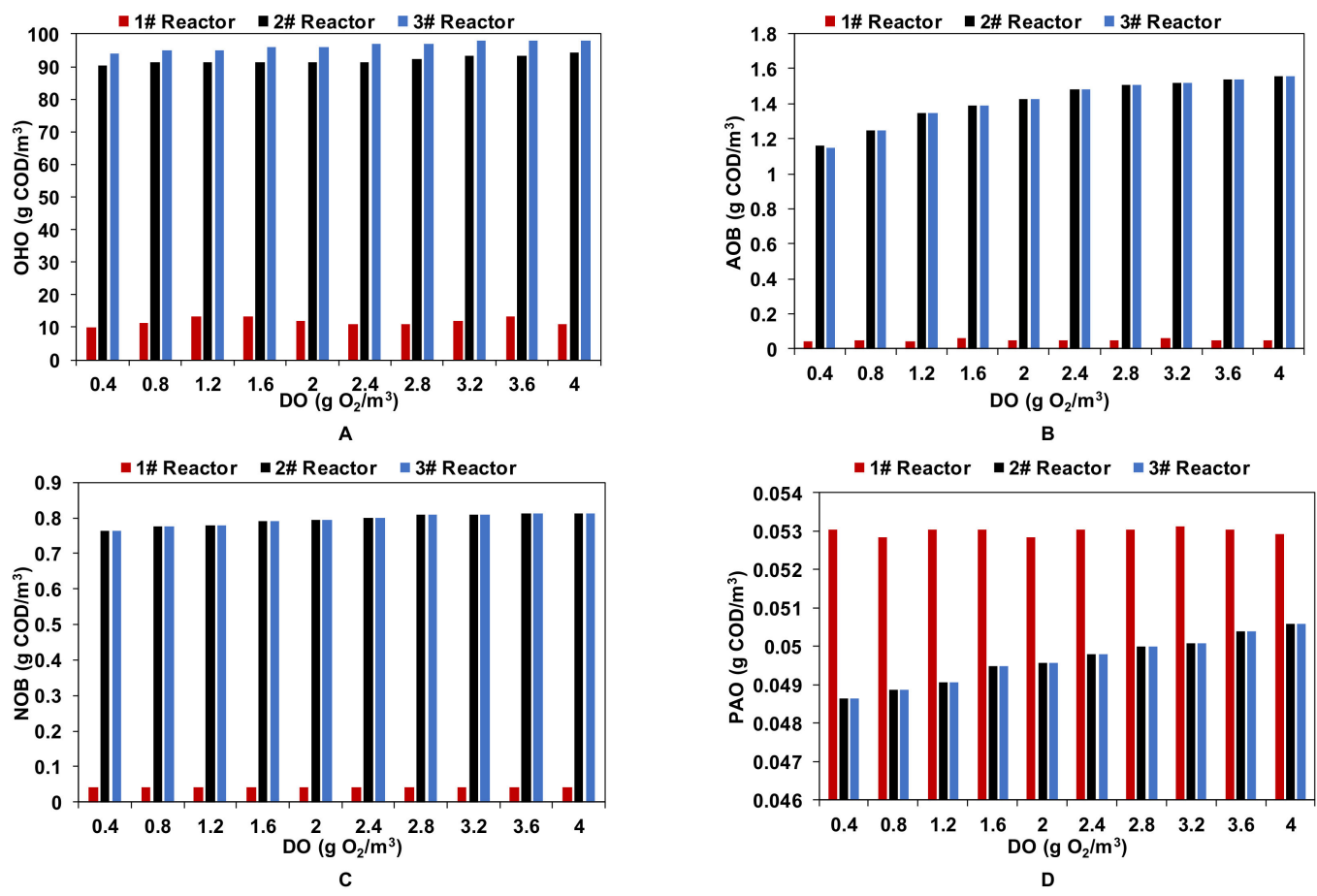

Figure 8. The influence of dissolved oxygen on the biomass of each reactor $(30 \mathrm{~d})$ : $(\mathbf{A}) \mathrm{OHO}$; (B) NOB; (C) AOB; (D) PAO.

The biomass of anoxic and aerobic reactors increased slightly with the increase in dissolved oxygen, and the content of $\mathrm{OHO}, \mathrm{AOB}$, and $\mathrm{NOB}$ in the anaerobic reactors were much lower than that in the anoxic and aerobic reactors. This is due to the backflow of the mixed liquid of the $\mathrm{A} 2 \mathrm{O}$ process, which causes the pollutants to provide more energy to the organisms in the reactors. The content of PAOs in the aerobic reactors was much lower than that in the anoxic and anaerobic reactors. This is because the anaerobic reactor mainly plays a role in releasing phosphorus. Pollutants can provide energy for the corresponding organisms, thereby promoting their growth. Similarly, with the increase of dissolved oxygen, its growth environment would be more conducive to the adsorption of pollutants by various bacterial species. However, the removal efficiency of pollutants is not only related to the amount of microorganisms but also hydraulic retention time and sludge retention time. This is also the reason why the removal efficiency of pollutants no longer improves after the dissolved oxygen reaches a certain value. In this study, the aerobic 
reactor at the desired DO setpoint was $4 \mathrm{~g} \mathrm{O}_{2} / \mathrm{m}^{3}$ compared with $0.2 \mathrm{~g} \mathrm{O}_{2} / \mathrm{m}^{3}$, the amount of OHO increased by $5 \%$, PAOs increased by $4 \%$, NOB increased by $6 \%$, and AOB increased by $35 \%$. Since AOB should be effectively promoted and NOB should be suppressed in partial nitrification anammox (PN/A) [14], the improvement of AOB was greater than that of NOB, which could effectively improve wastewater treatment efficiency.

\subsection{The Influence of the Reflux Ratio}

3.4.1. The Influence of the Reflux Ratio on the Effluent

Different from Single-BTF and Three-stage-BTF, with the construction of the A2O process, the reflow device would influence the sewage treatment effect. Among them, the mixed liquor reflux ratio (RR) mainly affects the denitrification removal effect, and the sludge reflux ratio mainly affects the microbial concentration in the system and biological phosphorus removal [62-64]. This is because the oxygen in the nitrate in the reflux liquid can be used as an electron donor, and the denitrification bacteria in the denitrification process use the organic matter in sewage as a carbon source. However, excessive reflux would increase the operating cost, and, at the same time, due to an insufficient carbon source in the reactor, it will also affect the reaction effect. In this article, the $\mathrm{A} 2 \mathrm{O}$ process is based on the biological trickling filter (BTF), and the amount of sludge produced by the biological trickling filter (BTF) was less than that of the traditional activated sludge system, so the mixed liquid reflux ratio (RR) was focused on.

The effect of different mixed liquid reflux ratios (RRs) on the sewage treatment effect is shown in Figure 9. Among them, as the RR increased, the effluent data of COD and TN decreased, and sewage treatment was best achieved at the RR of 2.25. This phenomenon is due to more denitrification in the anoxic reactor and more nitrification in the anaerobic reactor. At the same time, more COD was removed in the aerobic reactor. This result is basically similar to previous studies. Jung [65] pointed out that when the RRs were 1, 1.5, 2, and 3, the corresponding TN removal rate of each ratio was $54.10 \%, 69.80 \%, 76.60 \%$, and $81.90 \%$, respectively. Yan [66] pointed out that when the internal RR was increased from $100 \%$ to $300 \%$, the removal rates of chemical oxygen demand, ammonia nitrogen, total nitrogen, and total phosphorus all increased to varying degrees. The effluent concentration of $\mathrm{NH}_{3}-\mathrm{N}$ was the lowest at the reflux ratio of 0.75 , and the effluent concentration was the highest when the RR was 1.75. This was because, on the one hand, most of the ammoniating reaction was carried out in an aerobic reactor, which was less affected by the reflux ratio. On the other hand, more nitrate-nitrogen reflux would affect the decomposition of ammonia nitrogen in the nitrification reaction. The removal of TP was less affected by the RR. This was because $\mathrm{P}$ was released in the anaerobic reactor and absorbed by PAOs in the aerobic reactor. Its treatment effect was more affected by the sludge discharge unit, making PAO absorption in the aerobic reactor reach saturation concentration. Therefore, the chemical method should be used to remove P. 

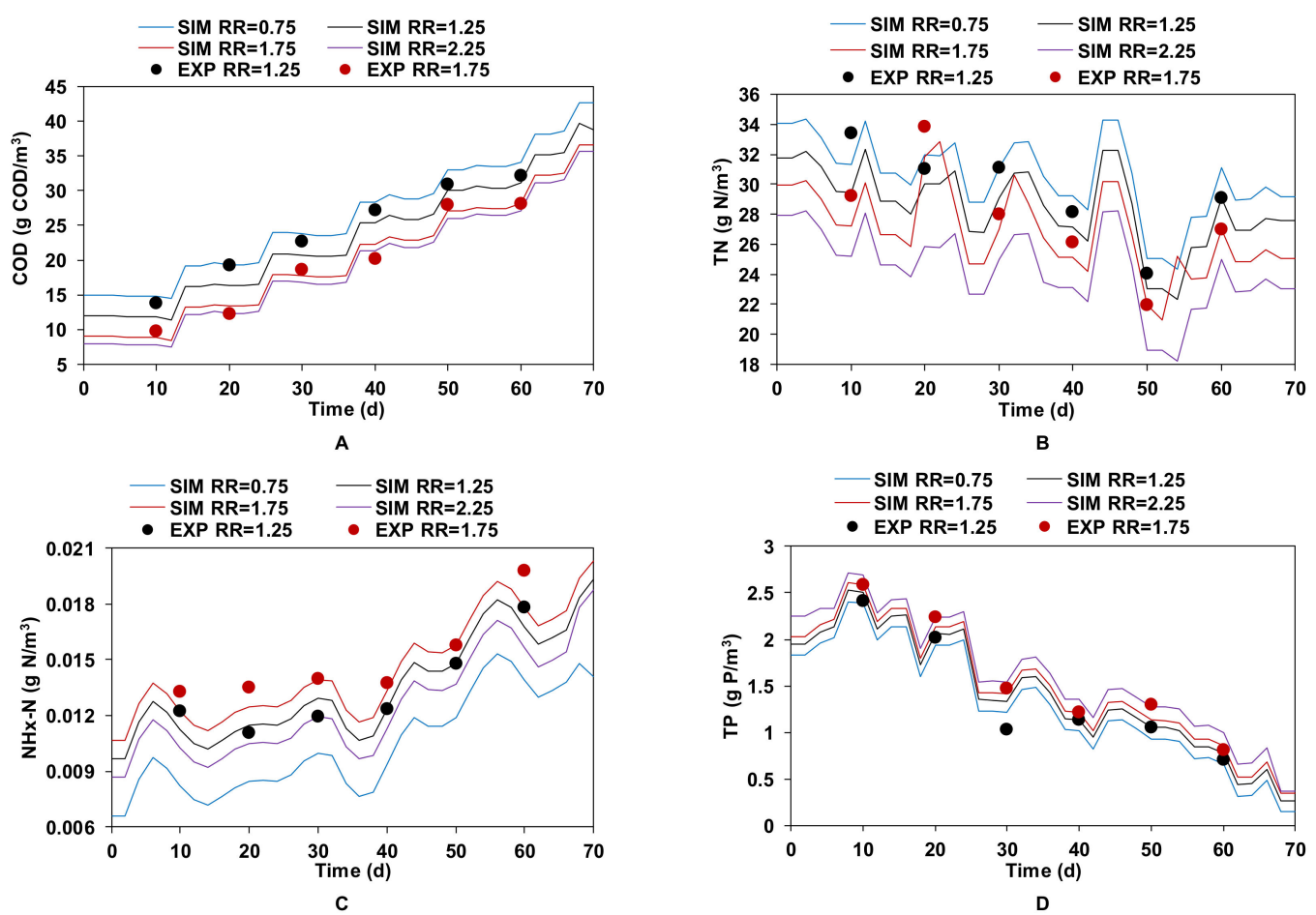

Figure 9. The influence of different mixed liquid RRs on the pollutant effluent effect: (A) COD; (B) $\mathrm{TN}$; (C) $\mathrm{NH}_{3}-\mathrm{N}$; (D) TP.

\subsubsection{The Effect of the Mixed Liquor Reflux Ratio on Biomass}

There are two main challenges in the partial nitrification anammox (PN/A) process. One is to inhibit the role of nitrite-oxidizing bacteria (NOB) in the short-cut nitrification process, and the other is to increase the residence time of $\mathrm{AOB}$ (ammonia-oxidizing bacteria) in the anaerobic ammonia oxidation process to promote the role of AOB [14].

The change of biomass under the action of different mixed liquor RRs is shown in Figure 10. Since the anaerobic reactor was not affected by the reflux ratio of the mixed liquid, the change in the anaerobic reactor was relatively small with the change of the reflux ratio of the mixed liquid. The numbers of $\mathrm{OHOs}, \mathrm{NOB}, \mathrm{AOB}$, and $\mathrm{PAOs}$ remained stable in the anaerobic reactor. The number of facultative and aerobic reactors has to increase because OHOs consume more COD. In the process of increasing the RR of the mixed liquid from 0.5 to 2.5 , the $\mathrm{OHO}$ in the facultative and aerobic reactors increased by about $32 \%$ each. With the increase of the RR of the mixed liquor, the number of NOB in the anoxic and aerobic reactors decreased slightly, while the number of $\mathrm{AOB}$ increased, and there was little difference in the numbers in the two anoxic and aerobic reactors. Among them, the number of AOB increased by about $20 \%$, and the number of NOB decreased by about $5 \%$, indicating that nitrite-oxidizing bacteria were effectively inhibited, and, at the same time, the effect of anammox was enhanced so that the number of TN was significantly reduced. Among them, the anaerobic ammonia oxidation process uses ammonia as the electron donor and nitrate or nitrite as the electron acceptor under anaerobic conditions to oxidize the ammonia into nitrogen, which is less expensive than full nitrification (ammonia oxidation to nitrate) on the index of oxygen supply. With the strengthening of the anammox process, energy consumption can be effectively reduced, and the removal efficiency of pollutants can be improved $[67,68]$. In addition, the distribution of PAOs in each reactor did not change significantly. It shows that although the concentration of TP in the effluent increases with the increase of the RR of the mixed solution, the increase is not obvious, and the number of PAOs does not change significantly. 

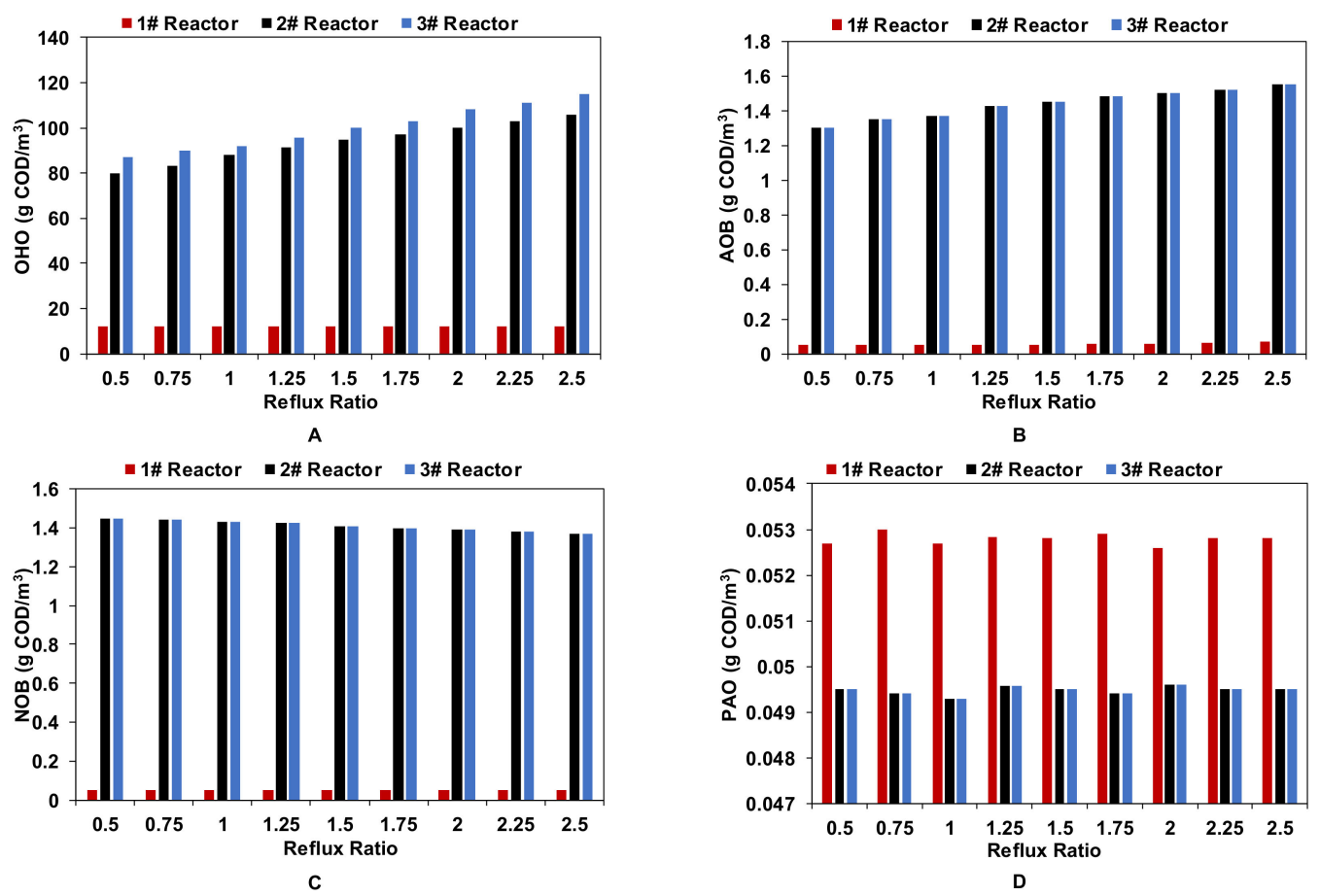

Figure 10. Changes of biomass in each reactor under different RRs (30 d): (A) OHO; (B) NOB; (C) AOB; (D) PAO.

\section{Conclusions}

The wastewater treatment performances of the three-stage biological trickling filter based on A2O (A2O-BTF), the ordinary three-stage biological trickling filter (Three-StageBTF), and the single biological trickling filter (Single-BTF) were modeled, and the operating parameters of $\mathrm{A} 2 \mathrm{O}-\mathrm{BTF}$, such as temperature, dissolved oxygen, and reflux ratio, were optimized. As the temperature increased to the range of $13.94-21.6{ }^{\circ} \mathrm{C}$, the pollutant concentration in the effluent decreased. The increase of dissolved oxygen (DO) in the aerobic pool reduced the effluent concentration of pollutants, but when the dissolved oxygen reached a certain value, the effluent concentration would no longer decrease. Appropriately increasing the reflux ratio of the mixed solution within a certain range could effectively improve the removal effect of $\mathrm{COD}$ and $\mathrm{TN}$, but it will make the removal of $\mathrm{TP}$ drop slightly.

Author Contributions: Conceptualization, J.L. and Z.Z.; methodology, S.Y.; software, J.L.; data curation, Y.Y. (Yixing Yuan); writing — original draft preparation, Y.Y. (Yuan Yuan); writing-review and editing, J.L.; project administration, S.Y.; funding acquisition, Y.Y. (Yixing Yuan) All authors have read and agreed to the published version of the manuscript.

Funding: This research received no external funding.

Institutional Review Board Statement: Not applicable.

Informed Consent Statement: Not applicable.

Data Availability Statement: Not applicable.

Acknowledgments: We would like to thank the professional reviewers and the editors.

Conflicts of Interest: The authors declare no conflict of interest. 


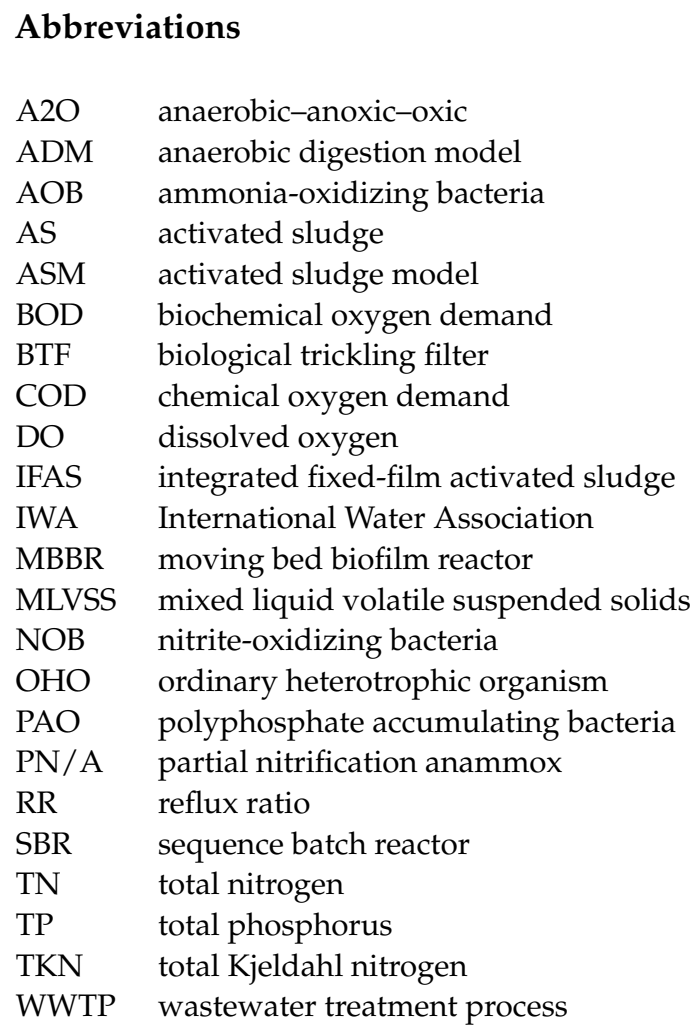

\section{References}

1. Ahn, J.H.; Kwan, T.; Chandran, K. Comparison of partial and full nitrification processes applied for treating high-strength nitrogen wastewaters: Microbial ecology through nitrous oxide production. Environ. Sci. Technol. 2011, 45, 2734-2740. [CrossRef]

2. Gullicks, H.; Hasan, H.; Das, D.; Morretti, C.; Hung, Y.T. Biofilm Fixed Film Systems. Water 2011, 3, 843-868. [CrossRef]

3. Ibrahim, S.; El-Liethy, M.A.; Abia, A.L.K.; Abdel-Gabbar, M.; Al-Zananty, A.M.; Kamel, M.M. Design of a bioaugmented multistage biofilter for accelerated municipal wastewater treatment and deactivation of pathogenic microorganisms. Sci. Total Environ. 2020, 703, 134786. [CrossRef]

4. Li, J.; Jin, Y.; Guo, Y.; He, J. Enhancement of phosphorus removal in a low temperature $\mathrm{A}^{2} / \mathrm{O}$ process by anaerobic phosphorus release of activated sludge. Water Sci. Technol. 2013, 67, 2437-2443. [CrossRef] [PubMed]

5. Pan, Z.; Zhou, J.; Lin, Z.; Wang, Y.; Zhao, P.; Zhou, J.; Liu, S.; He, X. Effects of COD/TN ratio on nitrogen removal efficiency, microbial community for high saline wastewater treatment based on heterotrophic nitrification-aerobic denitrification process. Bioresour. Technol. 2020, 301. [CrossRef] [PubMed]

6. Golshan, M.; Jorfi, S.; Haghighifard, N.J.; Takdastan, A.; Ghafari, S.; Rostami, S.; Ahmadi, M. Development of salt-tolerant microbial consortium during the treatment of saline bisphenol A-containing wastewater: Removal mechanisms and microbial characterization. J. Water Process Eng. 2019, 32. [CrossRef]

7. Ghosh, S.; Chakraborty, S. Influence of inoculum variation on formation and stability of aerobic granules in oily wastewater treatment. J. Environ. Manage. 2019, 248. [CrossRef] [PubMed]

8. Ahmadi, M.; Ahmadmoazzam, M.; Saeedi, R.; Abtahi, M.; Ghafari, S.; Jorfi, S. Biological treatment of a saline and recalcitrant petrochemical wastewater by using a newly isolated halo-tolerant bacterial consortium in MBBR. Desalin. Water Treat. 2019, 167, 84-95. [CrossRef]

9. Hodgson, B.; Sharvelle, S. Development of generalized empirical models for comparing effectiveness of wastewater nutrient removal technologies. Environ. Sci. Pollut. Res. 2019, 26, 27915-27929. [CrossRef]

10. Ravishankar, H.; Moazzem, S.; Jegatheesan, V. Performance evaluation of A2O MBR system with graphene oxide (GO) blended polysulfone (PSf) composite membrane for treatment of high strength synthetic wastewater containing lead. Chemosphere 2019, 234, 148-161. [CrossRef]

11. Yang, C.C.; Lu, M.S.; Dao, K.C.; Lin, J.W.; Chou, Y.H.; Tsai, Y.P. Comparison of the Influences of Cadmium Toxicity to Phosphate Removal in Activated Sludge Separately Fed by Glucose and Acetic Acid as Carbon Sources. Water 2020, 12, 1205. [CrossRef]

12. Qian, M.; Yang, L.; Chen, X.; Li, K.; Xue, W.; Li, Y.; Zhao, H.; Cao, G.; Guan, X.; Shen, G. The treatment of veterinary antibiotics in swine wastewater by biodegradation and Fenton-like oxidation. Sci. Total Environ. 2020, 710, 136299. [CrossRef]

13. Park, J.; Kim, C.; Hong, Y.; Lee, W.; Chung, H.; Jeong, D.H.; Kim, H. Distribution and Removal of Pharmaceuticals in Liquid and Solid Phases in the Unit Processes of Sewage Treatment Plants. Int. J. Env. Res. Public Health 2020, 17, 687. [CrossRef] 
14. Tao, C.; Hamouda, M.A. Steady-state modeling and evaluation of partial nitrification-anammox (PNA) for moving bed biofilm reactor and integrated fixed-film activated sludge processes treating municipal wastewater. J. Water Process Eng. 2019, $31,100854$. [CrossRef]

15. Leyva-Diaz, J.C.; Monteoliva-Garcia, A.; Martin-Pascual, J.; Munio, M.M.; Garcia-Mesa, J.J.; Poyatos, J.M. Moving bed biofilm reactor as an alternative wastewater treatment process for nutrient removal and recovery in the circular economy model. Bioresour. Technol. 2020, 299. [CrossRef]

16. Cramer, M.; Traenckner, J. Development of Decay in Biofilms under Starvation Conditions-Rethinking of the Biomass Model. Water 2020, 12, 1249. [CrossRef]

17. Cramer, M.; Tranckner, J.; Kotzbauer, U. Kinetic of denitrification and enhanced biological phosphorous removal (EBPR) of a trickling filter operated in a sequence-batch-reactor-mode (SBR-TF). Environ. Technol. 2019, 10. [CrossRef]

18. Naz, I.; Saroj, D.P.; Mumtaz, S.; Ali, N.; Ahmed, S. Assessment of biological trickling filter systems with various packing materials for improved wastewater treatment. Environ. Technol. 2015, 36, 424-434. [CrossRef]

19. Akratos, C.S.; Tatoulis, T.I.; Tekerlekopoulou, A.G. Biotreatment of Winery Wastewater Using a Hybrid System Combining Biological Trickling Filters and Constructed Wetlands. Appl. Sci. 2020, 10, 619. [CrossRef]

20. Diez-Montero, R.; Castrillo, M.; Casao, M.; Tejero, I. Model-based evaluation of a trickling filter facility upgrade to biological nutrient removal. Sci. Total Environ. 2019, 661, 187-195. [CrossRef]

21. Aziz, S.Q.; Ali, S.M. Characterization of municipal and dairy wastewaters with 30 quality parameters and potential wastewater treatment by biological trickling filters. Int. J. Green Energy 2017, 14, 1156-1162. [CrossRef]

22. Shahriari, T.; Shokouhi, M. Textile wastewater treatment using biological trickling filter with natural media in cold weather (case study: Motahari textile factory). Fresenius Environ. Bull. 2018, 27, 779-786.

23. Zhang, X.; Wang, Y.; Zhong, Z.; Shao, Q.; Wang, Y.; Li, W. Bacterial complexes of Bacillus subtilis and Pseudomonas stutzeri alter the microbial composition in grass carp water. Aquacult. Int. 2019, 27, 303-312. [CrossRef]

24. Yu, D.; Yang, J.; Fang, X.; Ren, H. Simultaneous efficient removal of high-strength ammonia nitrogen and chemical oxygen demand from landfill leachate by using an extremely high ammonia nitrogen-resistant strain. Biotechnol. Appl. Biochem. 2015, 62, 357-368. [CrossRef]

25. Sekar, S.; Sivaprakasam, S.; Mahadevan, S. Investigations on ultraviolet light and nitrous acid induced mutations of halotolerant bacterial strains for the treatment of tannery soak liquor. Int. Biodeterior. Biodegrad. 2009, 63, 176-181. [CrossRef]

26. Zhou, H.; Li, X.; Xu, G.; Yu, H. Overview of strategies for enhanced treatment of municipal/domestic wastewater at low temperature. Sci. Total Environ. 2018, 643, 225-237. [CrossRef]

27. Gomez-Rios, D.; Ramirez-Malule, H.; Neubauer, P.; Junne, S.; Rios-Estepa, R. Degradation Kinetics of Clavulanic Acid in Fermentation Broths at Low Temperatures. Antibiotics 2019, 8, 6. [CrossRef]

28. Kumwimba, M.N.; Zhu, B.; Wang, T.; Dzakpasu, M.; Li, X. Nutrient dynamics and retention in a vegetated drainage ditch receiving nutrient-rich sewage at low temperatures. Sci. Total Environ. 2020, 741. [CrossRef]

29. Maurer, M.; Gujer, W. Dynamic modelling of enhanced biological phosphorus and nitrogen removal in activated sludge systems. Water Sci. Technol. 1998, 38, 203-210. [CrossRef]

30. Gujer, W.; Henze, M.; Mino, T.; van Loosdrecht, M. Activated Sludge Model No. 3. Water Sci. Technol. 1999, 39, 183-193. [CrossRef]

31. Watari, T.; Hata, Y.; Hirakata, Y.; Nguyet, P.N.; Nguyen, T.H.; Maki, S.; Hatamoto, M.; Sutani, D.; Setia, T.; Yamaguch, T. Performance evaluation of down-flow hanging sponge reactor for direct treatment of actual textile wastewater; Effect of effluent recirculation to performance and microbial community. J. Water Process Eng. 2021, 39, 8. [CrossRef]

32. Abou-Elela, S.I.; Hellal, M.S.; Aly, O.H.; Abo-Elenin, S.A. Decentralized wastewater treatment using passively aerated biological filter. Environ. Technol. 2019, 40, 250-260. [CrossRef] [PubMed]

33. Zeng, W.; Li, L.; Yang, Y.; Zhang, Y.; Peng, Y. Effect of nitrite accumulation on enhanced biological phosphorus removal (EBPR) in $\mathrm{A}_{2} \mathrm{O}$ process treating domestic wastewater. Huan Jing Ke Xue 2010, 31, 2105-2112. [PubMed]

34. Makuwa, S.; Tlou, M.; Fosso-Kankeu, E.; Green, E. Evaluation of Fecal Coliform Prevalence and Physicochemical Indicators in the Effluent from a Wastewater Treatment Plant in the North-West Province, South Africa. Int. J. Env. Res. Public Health 2020, $17,6381$. [CrossRef]

35. Cao, G.; Wang, S.; Peng, Y.; Miao, Z. Biological nutrient removal by applying modified four step-feed technology to treat weak wastewater. Bioresour. Technol. 2013, 128, 604-611. [CrossRef]

36. Peng, Y.; Ge, S. Enhanced nutrient removal in three types of step feeding process from municipal wastewater. Bioresour. Technol. 2011, 102, 6405-6413. [CrossRef]

37. Huisman, J.L.; Gujer, W. Modelling wastewater transformation in sewers based on ASM3. Water Sci. Technol. 2002, 45, 51-60. [CrossRef]

38. Elawwad, A.; Zaghloul, M.; Abdel-Halim, H. Simulation of municipal-industrial full scale WWTP in an arid climate by application of ASM3. J. Water Reuse Desalin. 2017, 7, 37-44. [CrossRef]

39. Otuzalti, M.M.; Perendeci, N.A. Modeling of real scale waste activated sludge anaerobic digestion process by Anaerobic Digestion Model 1 (ADM1). Int. J. Green Energy 2018, 15, 454-464. [CrossRef]

40. Dereli, R.K.; Ersahin, M.E.; Ozgun, H.; Ozturk, I.; Aydin, A.F. Applicability of Anaerobic Digestion Model No. 1 (ADM1) for a specific industrial wastewater: Opium alkaloid effluents. Chem. Eng. J. 2010, 165, 89-94. [CrossRef] 
41. Baeten, J.E.; Batstone, D.J.; Schraa, O.J.; van Loosdrecht, M.C.M.; Volcke, E.I.P. Modelling anaerobic, aerobic and partial nitritationanammox granular sludge reactors-A review. Water Res. 2019, 149, 322-341. [CrossRef]

42. Seuntjens, D.; Han, M.; Kerckhof, F.M.; Boon, N.; Al-Omari, A.; Takacs, I.; Meerburg, F.; De Mulder, C.; Wett, B.; Boot, C.; et al. Pinpointing wastewater and process parameters controlling the AOB to NOB activity ratio in sewage treatment plants. Water Res. 2018, 138, 37-46. [CrossRef]

43. Gazsó, Z.; Házi, F.; Kenyeres, I.; Váci, L. Full-scale wastewater treatment plant simulation for real-time optimization. Water Pract. Technol. 2017, 12, 848-856. [CrossRef]

44. Chuang, H.; Ohashi, A.; Imachi, H.; Tandukar, M.; Harada, H. Effective partial nitrification to nitrite by down-flow hanging sponge reactor under limited oxygen condition. Water Res. 2007, 41, 295-302. [CrossRef]

45. Watari, T.; Vazquez, C.L.; Hatamoto, M.; Yamaguchi, T.; van Lier, J.B. Development of a single-stage mainstream anammox process using a sponge-bed trickling filter. Environ. Technol. 2020. [CrossRef]

46. Guillen, J.A.S.; Jayawardana, L.K.M.C.B.; Vazquez, C.M.L.; Cruz, L.M.O.; Brdjanovic, D.; van Lier, J.B. Autotrophic nitrogen removal over nitrite in a sponge-bed trickling filter. Bioresour. Technol. 2015, 187, 314-325. [CrossRef]

47. Tian, X.; Guo, X.; Yuan, X. Effects of Influent Organic Loading on Removal of Nitrogen and Phosphorus from the Three Stage Bio-Trickling Filters. Environ. Engineer. 2017, 35, 29-34.

48. Bai, X. The Optimization Research about the Operation of Wastewater Treatment Plant by Biowin Simulation Model. Master's Thesis, Kunming University of Science and Technology, Kunming, China, 2016.

49. Ge, S.; Wang, S.; Yang, X.; Qiu, S.; Li, B.; Peng, Y. Detection of nitrifiers and evaluation of partial nitrification for wastewater treatment: A review. Chemosphere 2015, 140, 85-98. [CrossRef]

50. Onwosi, C.O.; Igbokwe, V.C.; Odimba, J.N.; Eke, I.E.; Nwankwoala, M.O.; Iroh, I.N.; Ezeogu, L.I. Composting technology in waste stabilization: On the methods, challenges and future prospects. J. Environ. Manag. 2017, 190, 140-157. [CrossRef]

51. Chang, Y.; Lai, J.-Y.; Lee, D.-J. Thermodynamic parameters for adsorption equilibrium of heavy metals and dyes from wastewaters: Research updated. Bioresour. Technol. 2016, 222, 513-516. [CrossRef]

52. Brown, E.V.; Enzminger, J.D. Temperature profile and heat-transfer model for a chemical waste-water treatment-plant. Environ. Prog. 1991, 10, 159-168. [CrossRef]

53. Kanda, R.; Kishimoto, N.; Hinobayashi, J.; Hashimoto, T. Effects of recirculation rate of nitrified liquor and temperature on biological nitrification-denitrification process using a trickling filter. Water Environ. J. 2016, 30, 190-196. [CrossRef]

54. Chen, Y.; Lan, S.; Wang, L.; Dong, S.; Zhou, H.; Tan, Z.; Li, X. A review: Driving factors and regulation strategies of microbial community structure and dynamics in wastewater treatment systems. Chemosphere 2017, 174, 173-182. [CrossRef]

55. Sankaran, S.; Khanal, S.K.; Jasti, N.; Jin, B.; Pometto, A.L.; van Leeuwen, J. Use of Filamentous Fungi for Wastewater Treatment and Production of High Value Fungal Byproducts: A Review. Crit. Rev. Environ. Sci. Technol. 2010, 40, 400-449. [CrossRef]

56. Varma, M.; Gupta, A.K.; Ghosal, P.S.; Majumder, A. A review on performance of constructed wetlands in tropical and cold climate: Insights of mechanism, role of influencing factors, and system modification in low temperature. Sci. Total Environ. 2020, 755, 142540. [CrossRef]

57. Lotti, T.; Kleerebezem, R.; Hu, Z.; Kartal, B.; Jetten, M.S.M.; van Loosdrecht, M.C.M. Simultaneous partial nitritation and anammox at low temperature with granular sludge. Water Res. 2014, 66, 111-121. [CrossRef]

58. Li, J.; Zhang, L.; Peng, Y.; Zhang, Q. Effect of low COD/N ratios on stability of single-stage partial nitritation/anammox (SPN/A) process in a long-term operation. Bioresour. Technol. 2017, 244. [CrossRef]

59. Gani, K.M.; Awolusi, O.O.; Khan, A.A.; Kumari, S.; Bux, F. Potential strategies for the mainstream application of anammox in treatment of anaerobic effluents-A review. Crit. Rev. Environ. Sci. Technol. 2020. [CrossRef]

60. Cao, S.; Du, R.; Zhou, Y. Coupling anammox with heterotrophic denitrification for enhanced nitrogen removal: A review. Crit. Rev. Environ. Sci. Technol. 2020. [CrossRef]

61. Kunapongkiti, P.; Rongsayamanont, C.; Nayranritsattha, P.; Limpiyakorn, T. Application of cell immobilization technology to promote nitritation: A review. Environ. Eng. Res. 2020, 25, 807-818. [CrossRef]

62. Wang, L.; Shen, H.; Zhang, H.; Wu, X.; Wang, X. Experimental Studies on The Effects of Different Carbon Sources on Phosphorus Removal During Denitrifying Process in the Parallel A(2)O-Mbr System. Environ. Eng. Manag. J. 2013, 12, 1833-1836. [CrossRef]

63. Peng, S.; Kong, Q.; Deng, S.; Xie, B.; Yang, X.; Li, D.; Hu, Z.; Sun, S. Application potential of simultaneous nitrification/Fe0-supported autotrophic denitrification (SNAD) based on iron-scraps and micro electrolysis. Sci. Total Environ. $2020,711$. [CrossRef]

64. Wang, Y.; Liu, B.; Zhang, K.; Liu, Y.; Xu, X.; Wang, H. In-situ sludge reduction and simultaneous phosphorus removal in A(2)O and side-stream induced crystallization coupling system for treating domestic wastewater. Desalin. Water Treat. 2019, 146, 165-175. [CrossRef]

65. Jung, J.; Cho, Y.; Kim, Y. Efficiencies of Organic Matters and Nitrogen Removal at Different Recycle Ratios in a SMBR System. Ksce J. Civil Eng. 2019, 23, 985-991. [CrossRef] 
66. Yan, X.; Zheng, J.; Han, Y.; Eiu, J.; Sun, J. Experimental studies on the effects of different carbon sources on phosphorus removal during denitrifying process in the parallel A(2)O-mbr system. Environ. Prot. Eng. 2019, 45, 87-101.

67. Li, J.; Li, J.; Peng, Y.; Wang, S.; Zhang, L.; Yang, S.; Li, S. Insight into the impacts of organics on anammox and their potential linking to system performance of sewage partial nitrification-anammox (PN/A): A critical review. Bioresour. Technol. 2020, 300. [CrossRef] [PubMed]

68. Zhang, M.; Wang, S.; Ji, B.; Lin, Y. Towards mainstream deammonification of municipal wastewater: Partial nitrification-anammox versus partial denitrification-anammox. Sci. Total Environ. 2019, 692, 393-401. [CrossRef] 